\title{
The Suppressor of Transgene RNA Silencing Encoded by Cucumber mosaic virus Interferes with Salicylic Acid-Mediated Virus Resistance
}

\author{
Liang-Hui Ji and Shou-Wei Ding \\ Molecular Virology Laboratory, Institute of Molecular Agrobiology, National University of Singapore, \\ 1 Research Link, 117604 Singapore \\ Submitted 20 December 2000; Accepted 16 February 2001.
}

\begin{abstract}
The Cucumber mosaic virus (CMV)-encoded $2 \mathrm{~b}$ protein (Cmv2b) is a nuclear protein that suppresses transgene RNA silencing in Nicotiana benthamiana. Cmv2b is an important virulence determinant but nonessential for systemic spread in $N$. glutinosa, in contrast to its indispensable role for systemic infections in cucumber. Here, we report that Cmv2b became essential for systemic infections in older $N$. glutinosa plants or in young seedlings pretreated with salicylic acid (SA). Expression of Cmv2b from the genome of either CMV or Tobacco mosaic virus significantly reduced the inhibitory effect of $\mathrm{SA}$ on virus accumulation in inoculated leaves and systemic leaves. A close correlation is demonstrated between $\mathrm{Cmv} 2 \mathrm{~b}$ expression and a reduced $\mathrm{SA}$-dependent induction of the alternative oxidase gene, a component of the recently proposed SAregulated antiviral defense. These results collectively reveal a novel activity of $\mathrm{Cmv} 2 \mathrm{~b}$ in the inhibition of SAmediated virus resistance. We used a $N$. tabacum line expressing a bacterial $n a h G$ transgene that degrades SA to provide evidence for a $\mathrm{Cmv} 2 \mathrm{~b}$-sensitive antiviral defense mechanism in tobacco in which SA acts as a positive modifier but not as an essential component. We propose that SA induces virus resistance by potentiating a RNAsilencing antiviral defense that is targeted by $\mathrm{Cmv} 2 \mathrm{~b}$.
\end{abstract}

Additional keywords: disease resistance; pathogenesis-related proteins; posttranscriptional gene silencing; systemic acquired resistance.

Plant defense against pathogens and pests consists of a complex network regulated largely by a few low-molecularweight compounds, including salicylic acid (SA), jasmonic acid (JA), and ethylene (Dong 1998; Glazebrook 1999; Reymond and Farmer 1998). SA is an important component in the signal transduction pathway leading to systemic acquired resistance (SAR), a resistance mechanism that is effective against a broad spectrum of pathogens, including bacteria, fungi, and viruses (Raskin 1992; Ryals et al. 1996). The most powerful inducer for SA synthesis and SAR induction is the hypersensitive response, which occurs when a host plant car-

Corresponding author: S.-W. Ding;. Current address: Department of Plant Pathology, University of California, Riverside 92521-0122, U.S.A.; E-mail: shou-wei.ding@ucr.edu rying a resistance gene is challenged by a pathogen carrying a matching avirulence gene (Staskawicz et al. 1995). SA may induce resistance via multiple mechanisms, including the induction of antimicrobial pathogenesis-related (PR) proteins, potentiation of $\mathrm{H}_{2} \mathrm{O}_{2}$ production, and cell death (Bowles 1990; Durner et al. 1997; Mur et al. 1996; Rao and Davis 1999; Shirasu et al. 1997; Uknes et al. 1993). The essential role of SA in the induction of SAR has been demonstrated in transgenic plants expressing the SA-degrading enzyme, salicylate hydroxylase, encoded by the nahG gene of Pseudomonas putida. These plants are unable to accumulate SA and are compromised in SAR (Friedrich et al. 1995; Gaffney et al. 1993; Lawton et al. 1995; Mur et al. 1997). In addition, tobacco plants suppressed in the expression of phenylalanine ammonia lyase, a rate-limiting enzyme in the SA biosynthesis pathway, were defective in developing SAR (Pallas et al. 1996). In several plant species, including tobacco (Nicotiana tabacum), exogenous application of SA or functional analogs such as benzo $(1,2,3)$ thiadiazole-7-carbothioic acid S-methyl ester and 2,6-dichloroisonicotinic acid also is sufficient for the induction of SAR (Friedrich et al. 1996; Lawton et al. 1996; Ward et al. 1991). To date, the only plant gene identified as essential for the establishment of SAR that is functional downstream of SA production is $\mathrm{Nprl}$ (nonexpresser of $\mathrm{PR}$ ) from Arabidopsis thaliana (Cao et al. 1997; Ryals et al. 1997).

Although expression of PR genes is commonly used as a molecular marker for the induction of resistance to viruses, none of the SA-inducible PR proteins identified have been shown to act against viruses (Bowles 1990; Linthorst et al. 1989). The mechanism by which SA mediates resistance to viruses (Hooft van Huijsdijnen et al. 1986; White et al. 1983) remains poorly understood. Recently, it was reported that SA treatment inhibited genome replication of Tobacco mosaic virus (TMV) in inoculated leaves of a susceptible tobacco variety, resulting in a delay in the onset of systemic symptoms at the whole-plant level (Chivasa et al. 1997). Significantly, salicylhydroxamic acid (SHAM), an inhibitor of the mitochondrial enzyme alternative oxidase (AOX), antagonized the inhibitory effect of SA to viruses but not to fungal or bacterial pathogens (Chivasa et al. 1997). It was proposed that SAinduced resistance against pathogens may have branched, forming an independent, virus-specific resistance pathway (Murphy et al. 1999). Interestingly, SA treatment has no obvious effect on the accumulation of RNAs of Cucumber mosaic virus $(\mathrm{CMV})$ in inoculated tobacco leaves. Instead, SA- 
mediated resistance to CMV is attributed to an inhibition of systemic virus movement, which also is sensitive to SHAM (Naylor et al. 1998).

On the basis of its wide host range ( $>1,000$ plant species) and worldwide distribution, CMV can be considered one of the most successful plant pathogenic viruses (Gallitelli 2000; Palukaitis et al. 1992). CMV contains a tripartite singlestranded RNA genome that encodes five proteins required for replication, movement, and encapsidation (Ding et al. 1994; Palukaitis et al. 1992). The $2 b$ gene is located toward the $3^{\prime}$ end of RNA 2 and is translated in vivo via RNA 4A, a subgenomic RNA of RNA 2 (Ding et al. 1994). Previous mutational analyses showed that the CMV $2 b$ protein $(\mathrm{Cmv} 2 \mathrm{~b})$ is essential for systemic virus spread in cucumber plants. CMV- $\Delta 2 b$, a mutant of CMV that does not express $\mathrm{Cmv} 2 \mathrm{~b}$, however, is able to systemically infect $N$. glutinosa plants, albeit with greatly reduced virulence (Ding et al. 1995a; Ding et al. 1996). Cmv2b was one of the first two viral proteins identified as suppressors of posttranscriptional gene silencing (PTGS) (Anandalakshmi et al. 1998; Brigneti et al. 1998; Kasschau and Carrington 1998) and contains a functional nuclear localization signal, which is required for efficient suppression of PTGS (Lucy et al. 2000). PTGS occurs via a targeted RNAdegrading process, which is independent of gene transcription, and recently has been referred to as "RNA silencing" (Baulcombe 1999; Ding 2000). RNA silencing is conserved in diverse eukaryotic organisms and represents an antiviral defense mechanism in plants (Covey et al. 1997; Ratcliff et al. 1997). Thus, this newly identified activity of Cmv2b in silencing suppression may explain why the protein is absolutely required for establishing systemic infections in cucumber plants.

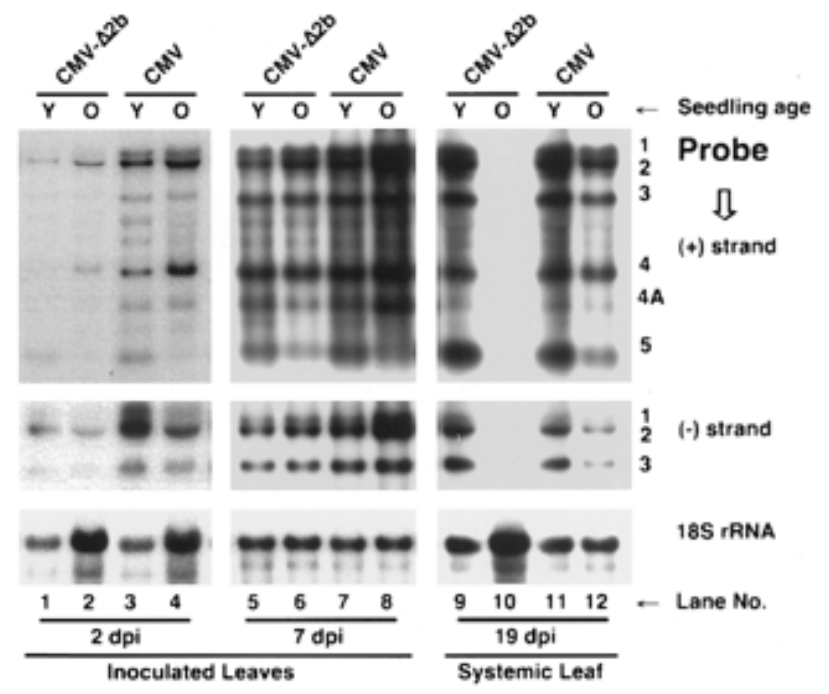

Fig. 1. Susceptibility of Nicotiana glutinosa seedlings of different developmental stages to Cucumber mosaic virus (CMV) and CMV- $\Delta 2 \mathrm{~b}$ (a mutant of CMV that does not express the CMV $2 b$ protein). Virions of CMV or CMV- $\Delta 2 \mathrm{~b}$ were inoculated onto the second and third true leaves of seedlings at either the 2-3 (Y) or 9-11 leaf stage (O). Total RNA was extracted from the inoculated leaves at 2 and 7 days postinoculation (dpi) and from the seventh leaf above the inoculated leaves at 19 dpi. Total RNA

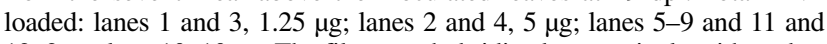
$12,2 \mu \mathrm{g}$; lane $10,10 \mu \mathrm{g}$. The filter was hybridized successively with probes specific for the (-) and (+) strands of CMV RNAs and for 18S rRNA. The CMV RNA species are indicated on the right.
The present study initially targeted two unrelated questions concerning CMV infections in Nicotiana species. The first considered why the silencing suppression function of $\mathrm{Cmv} 2 \mathrm{~b}$ is not required to establish systemic CMV infections in $N$. glutinosa and $N$. tabacum, in contrast to infections in cucumber (Ding et al. 1995a; Ding et al. 1996). The second concerned the molecular basis for the relative insensitivity of CMV to SA treatment compared with TMV or Potato virus X (PVX) (Murphy et al. 1999; Naylor et al. 1998). Here, we report that Cmv2b is essential for CMV to establish systemic infections in older N. glutinosa plants or young $N$. glutinosa seedlings that are pretreated with SA and provide evidence for a new Cmv2b activity in the inhibition of SA-mediated virus resistance. The possibility that $\mathrm{Cmv} 2 \mathrm{~b}$ has a single target that is important for RNA silencing and SA-mediated antiviral pathways is discussed.

\section{RESULTS}

\section{A CMV 2b-deletion mutant was unable}

to establish systemic infections in older $N$. glutinosa plants.

To further analyze the role of $\mathrm{Cmv} 2 \mathrm{~b}$ in the systemic infections of $N$. glutinosa by CMV, we made use of CMV- $\Delta 2 \mathrm{~b}$ (Ding et al. 1995a). CMV- $\Delta 2$ b contains a $U$ to A substitution at nucleotide 2,420 of RNA 2 that converts the fourth codon of the $2 \mathrm{~b}$ gene into a stop codon. When very young seedlings of two to three true leaves were used for inoculation, CMV- $\Delta 2 \mathrm{~b}$ displayed no detectable defect in systemic spread (Fig. 1). This was evidenced by the accumulation of similar levels of the (+)- and (-)-strand viral RNAs (Fig. 1, compare lane 9 with 11), as detected by Northern blot hybridization in the systemic leaves of plants infected with either CMV- $\Delta 2 \mathrm{~b}$ or wild-type CMV (hereafter referred to as CMV). As found previously, plants infected by $C M V-\Delta 2 b$ exhibited extremely mild systemic symptoms in contrast to the severe leaf mosaic and distortion caused by CMV (Ding et al. 1995a). It was noted that in inoculated leaves, $C M V-\Delta 2 b$ RNAs accumulated to approximately six- to eightfold levels lower than CMV at 2 days postinoculation (dpi) (Fig. 1, compare lane 1 with 3), although this difference diminished to less than twofold by 7 dpi (Fig. 1, compare lane 5 with 7). This reduced virus accumulation in the inoculated leaves during the early stages of infection seemed to have little effect on the subsequent systemic spread of CMV- $\Delta 2 \mathrm{~b}$ into the rest of the $16 \mathrm{~N}$. glutinosa plants analyzed. Sequence analysis of progeny-viral RNAs found no revertant or pseudorevertant CMV- $\Delta 2 \mathrm{~b}$ in the systemic leaves, as shown previously (Ding et al. 1995b). These data further confirm our earlier finding that $\mathrm{Cmv} 2 \mathrm{~b}$ is not required for systemic CMV infections in this host, although it does contribute to virulence determination (Ding et al. 1995a).

When inoculated onto the second and third true leaves of older seedlings (9 to 11 true leaves), CMV- $\Delta 2 \mathrm{~b}$ accumulated in the inoculated leaves, as determined at 2 and 7 dpi (Fig. 1, lanes 2 and 6). None of the plants inoculated with CMV- $\Delta 2 b$, however, showed any systemic symptoms, and Northern blot hybridization revealed no detectable CMV- $\Delta 2$ b RNAs in the systemic leaves. Figure 1 (right panel) shows one such analysis in which the total RNAs were extracted from the seventh leaf above the inoculated leaves of eight plants at 19 dpi. Note that the amount of RNA loaded in lane 10 was five times what was loaded in lanes 9, 11, and 12. No signal was detected in lane 10, even when the blot was exposed to X-ray film 100 
times longer than shown here. In contrast, CMV was able to establish systemic infections when inoculated onto the older seedlings (Fig. 1, lane 12). Nevertheless, the older plants were more resistant to CMV than were the young seedlings and supported a reduced (approximately threefold) accumulation of viral RNAs in inoculated (Fig. 1, compare lane 3 with 4) and systemic leaves (Fig. 1, compare lane 11 with 12). Thus, whereas $\mathrm{Cmv} 2 \mathrm{~b}$ is dispensable for systemic infections in young seedlings, it is essential for CMV to establish systemic infections in older $N$. glutinosa plants.

\section{Enhanced sensitivity of CMV- $\Delta 2 \mathrm{~b}$ to $\mathrm{SA}$ treatment in $N$. glutinosa.}

The role of Cmv2b in overcoming the enhanced virus resistance exhibited in older $N$. glutinosa plants prompted us to examine whether $\mathrm{Cmv} 2 \mathrm{~b}$ is related to a previously described insensitivity of CMV to SA (Naylor et al. 1998). SA pretreatment of young $N$. glutinosa seedlings reduced the severity of symptoms caused by CMV infections (Fig. 2) and delayed symptom appearance by at least 5 days. Although all of the water-treated control plants developed systemic symptoms by $7 \mathrm{dpi}$, approximately half of the SA-treated, CMV-inoculated plants did not develop visible systemic symptoms by $17 \mathrm{dpi}$ in two independent experiments. Northern blot hybridization analysis revealed that SA treatment marginally reduced the accumulation of CMV RNAs (an overall decrease of $25 \%$ for the five [+]-strand CMV RNAs) in the inoculated leaves at 4 dpi (Fig. 3, compare lane 3 with 4). By 8 dpi, no difference in viral RNA accumulation was detected between the water- and SA-treated plants (Fig. 3, compare lane 7 with 8). Neverthe-

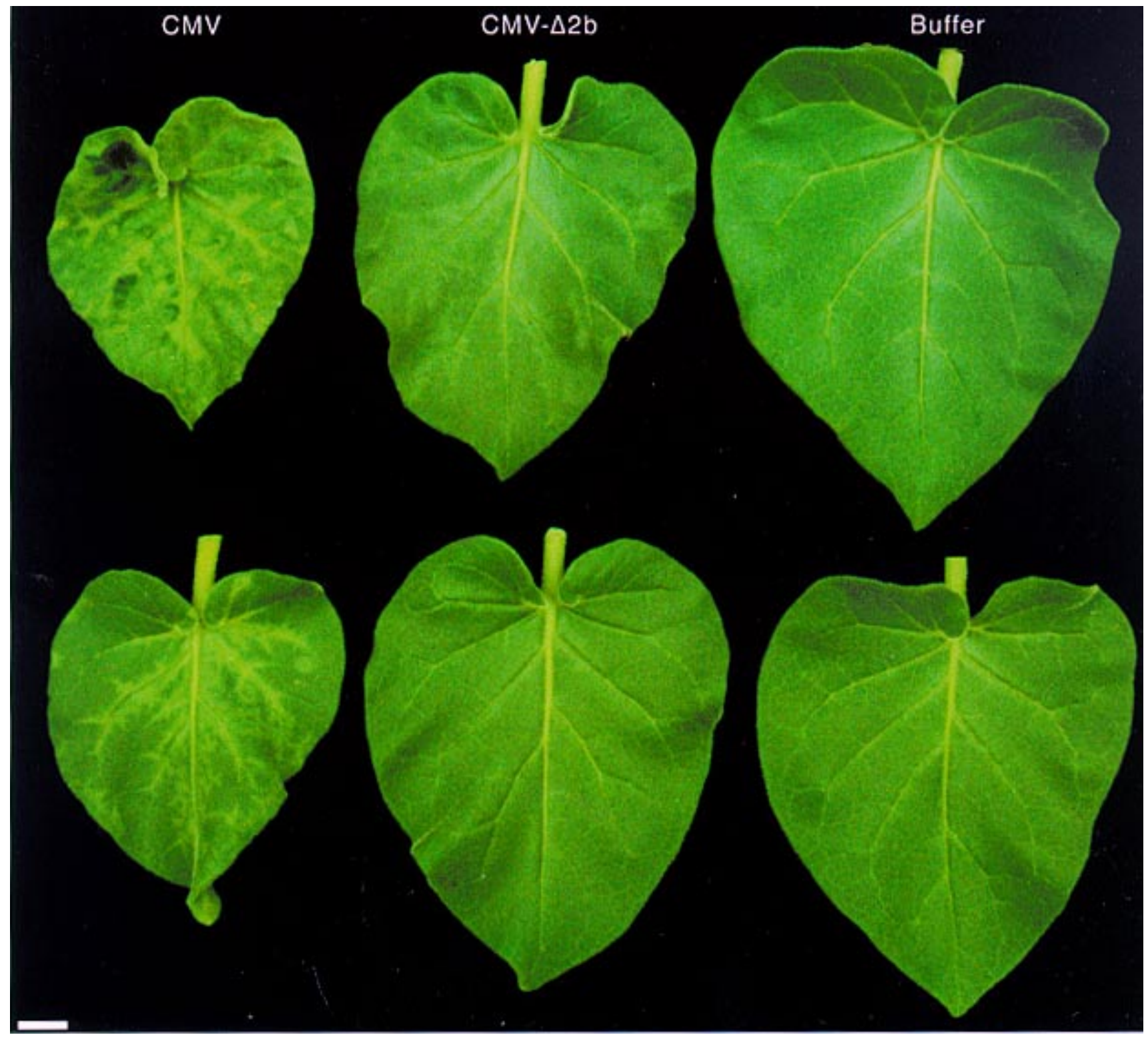

Fig. 2. Effect of salicylic acid (SA) on the pathogenicity of Cucumber mosaic virus (CMV) and CMV- $\Delta 2 \mathrm{~b}$ (a mutant of CMV that does not express the CMV $2 \mathrm{~b}$ protein) in Nicotiana glutinosa. $N$. glutinosa seedlings pretreated with $2 \mathrm{mM} \mathrm{SA}$ (lower row) or water (upper row) were inoculated with virions of CMV or CMV- $\Delta 2 \mathrm{~b}$ or mock inoculated only with buffer. After inoculation, SA treatment continued on alternate days, up to day 8 . The seventh leaf above the inoculated leaves was photographed at 17 days postinoculation. Scale bar $=1 \mathrm{~cm}$. 
less, SA treatment significantly reduced the accumulation of CMV RNAs (up to sevenfold) in the systemic leaves (Fig. 3, compare lane 11 with 12). These results essentially confirmed earlier observations with a different subgroup strain of CMV in N. tabacum, an alternative host (Naylor et al. 1998).

CMV- $\Delta 2$ b was significantly more sensitive to SA treatment than CMV. In particular, none of the SA-treated N. glutinosa plants developed systemic symptoms after inoculation with CMV- $\Delta 2$ b (Fig. 2). Northern blot hybridization analysis confirmed the absence of CMV- $\Delta 2 \mathrm{~b}$ RNAs in the systemic leaves (Fig. 3, lane 10), even though the RNA loading of this lane was 10 times that of lanes 9, 11, and 12. Furthermore, no signal was detected in lane 10 , even when the X-ray film was exposed 100 times longer than shown here. Thus, although young $N$. glutinosa seedlings normally would support a closeto-wild-type accumulation of CMV- $\Delta 2 \mathrm{~b}$ RNAs in the systemic leaves (Fig. 1, compare lane 9 with 11), SA treatment of these young plants effectively prevented the systemic spread of this CMV mutant. This suggests that Cmv2b may function as an antagonist to the SA-mediated virus resistance mechanism. The seedlings used here (five to six leaf) had matured slightly during the SA treatment period and thus might have become more resistant than those used in earlier experiments (Fig. 1). This may be the reason why CMV- $\Delta 2 \mathrm{~b}$ accumulated to a lower level than CMV in the systemic leaves of the watertreated control plants (Fig. 3, compare lane 9 with 11), although the reduction in the accumulation of the (-)-strand viral RNAs was much smaller than that of the (+)-strand RNAs.

The proposed role of $\mathrm{Cmv} 2 \mathrm{~b}$ as an antagonist to SAmediated resistance appears to function in the inoculated leaves as well (Fig. 3, left and middle panels). In the absence of Cmv2b expression, SA treatment caused a threefold reduction in the accumulation of (+)- and (-)-strand viral RNAs in

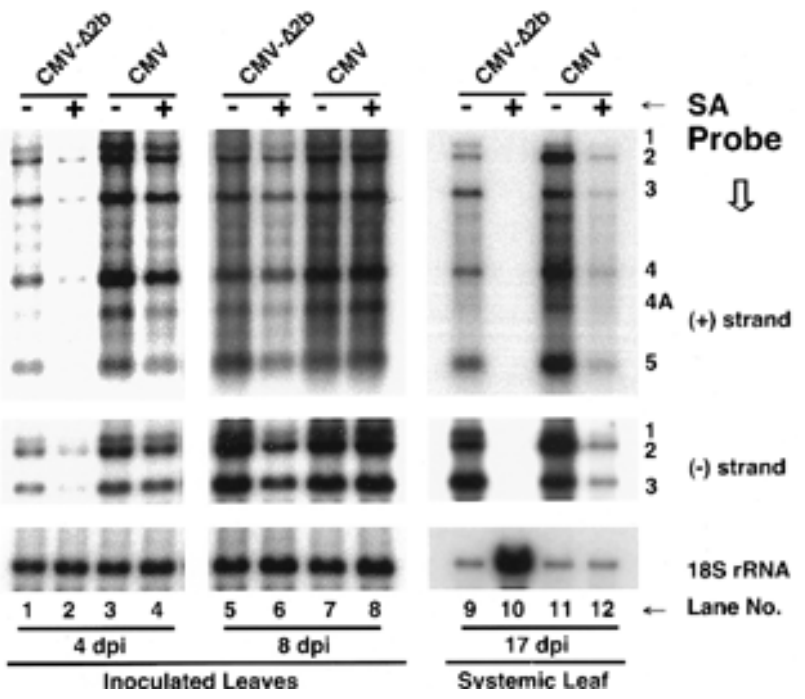

Fig. 3. Effect of salicylic acid (SA) on the accumulation of Cucumber mosaic virus (CMV) and CMV- $\Delta 2 \mathrm{~b}$ (a mutant of CMV that does not express the CMV 2b protein) RNAs in Nicotiana glutinosa. N. glutinosa seedlings pretreated with $2 \mathrm{mM} \mathrm{SA}(+)$ or water $(-)$ were inoculated with virions of CMV or CMV- $\Delta 2 \mathrm{~b}$. Leaf samples were pooled for RNA extraction at the time indicated at the bottom of each column. Total RNA loaded: lanes 1-8, $2 \mu \mathrm{g}$; lanes 9, 11, and 12, $0.5 \mu \mathrm{g}$; lane 10, $5 \mu \mathrm{g}$. The CMV RNA species are indicated on the right. inoculated leaves at 4 (Fig. 3, compare lane 1 with 2) and 8 dpi (Fig. 3, compare lane 5 with 6). Comparing these data with those described above for CMV, we conclude that Cmv2b plays a major role in the observed insensitivity of CMV to SA.

We next tested whether Cmv2b remains an active inhibitor of SA-mediated virus resistance when expressed from a heterologous virus. TMV-C2b contains the complete $\mathrm{Cmv} 2 \mathrm{~b}$ coding sequence inserted upstream of the coat protein (CP) gene of TMV and has been described previously ( $\mathrm{Li}$ et al. 1999). The expression of $C m v 2 b$ is controlled under an independent TMV CP subgenomic RNA promoter (Shivprasad et al. 1999). TMV-C $\Delta 2 \mathrm{~b}$ is identical to TMV-C2b in its nucleotide sequence, except for a single substitution that renders open reading frame $2 \mathrm{~b}$ noncoding, as in $\mathrm{CMV}-\Delta 2 \mathrm{~b}$. Because $N$. glutinosa is an incompatible host for TMV, we inoculated TMV-C2b and TMV-C $\Delta 2$ b onto N. tabacum cv. Samsun nn plants. Cmv2b had no detectable effect on TMV in plants treated with water because both in TMV-C2b, and TMV-C $\Delta 2 \mathrm{~b}$ accumulated to similar levels in the inoculated and systemic leaves (Fig. 4, compare lane 1 with 2 and 5 with 6). When inoculated onto Samsun nn seedlings pretreated with SA, however, Cmv2b expression was associated with an approxi-

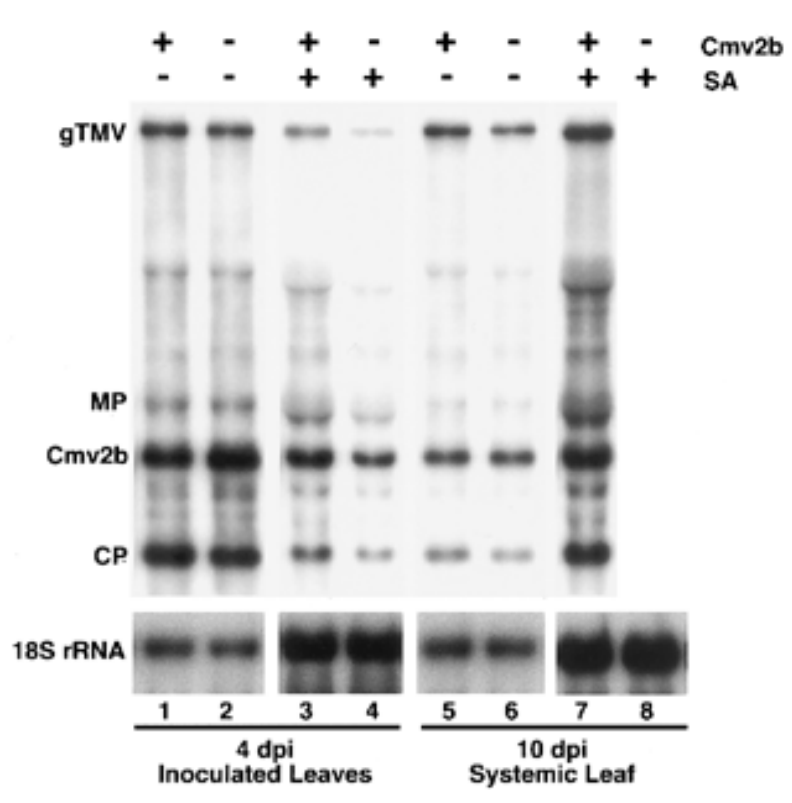

Fig. 4. Effect of Cmv2b (CMV 2b protein) expression on the sensitivity of Tobacco mosaic virus (TMV) to salicylic acid (SA). Nicotiana tabacum cv. Samsun nn seedlings pretreated for 5 days with water (lanes 1 and 2 and 5 and 6) or $2 \mathrm{mM} \mathrm{SA}$ (lanes 3 and 4 and 7 and 8) were inoculated with TMV-C2b (lanes 1, 3, 5, and 7) or TMV-C $\Delta 2 \mathrm{~b}$ (a mutant of CMV that does not express the CMV 2b protein; lanes 2, 4, 6, and 8). Lanes 1-4 were loaded with total RNA extracted from inoculated leaves that were collected at 4 days postinoculation (dpi); lanes 5-8 were loaded with total RNA extracted at $10 \mathrm{dpi}$ from the ninth systemic leaves above the inoculation point. Total RNA loaded: lanes 1, 2, 5, and 6, $1 \mu \mathrm{g}$; lanes 3 and 4, $5 \mu \mathrm{g}$; lanes 7 and 8, $10 \mu \mathrm{g}$. Blot was hybridized successively with a DNA fragment corresponding to the coat protein (CP) coding region of pTMV-30B and a cDNA probe for 18S rRNA. The positions of full-length genomic RNA (gTMV) and subgenomic RNAs encoding movement protein (MP) and CP are indicated on the left. Cmv2b indicates the position of the translatable and untranslatable $C m v 2 b$ subgenomic transcripts, which were confirmed by hybridization with a Cmv2b cDNA probe (data not shown). Identical exposure time (2 h) was used to obtain the images in each lane. 
mately 2.5-fold increase in the accumulation of genomic and subgenomic RNAs (Fig. 4, compare lane 3 with 4). In addition, SA-treated plants displayed visible systemic symptoms 8 to 9 dpi with TMV-C2b, whereas those inoculated with TMV$\mathrm{C} \Delta 2 \mathrm{~b}$ remained symptomless for up to $17 \mathrm{dpi}$ (not shown). Northern blot hybridization analysis of RNAs extracted from the upper, noninoculated leaves at 10 dpi showed that the accumulation of TMV-C $\Delta 2 \mathrm{~b}$ RNAs was undetectable (Fig. 4, lane 8), in contrast to TMV-C2b (Fig. 4, lane 7). These data indicate that $\mathrm{Cmv} 2 \mathrm{~b}$ also is an antagonist to SA-mediated resistance when expressed from a heterologous, SA-sensitive virus genome.

\section{Comv2b expression and Aox induction.}

The induction of Aox previously has been postulated to be involved in SA-mediated virus resistance (Chivasa and Carr 1998; Chivasa et al. 1997). Therefore, we examined whether the reduced sensitivity of CMV to SA was related to the expression of Aox. We found that Aox was induced rapidly by SA (Fig. 5A), peaking at approximately $4 \mathrm{~h}$ after SA application in either $N$. tabacum (Fig. 5A, lane 4) or $N$. glutinosa (data not shown) before dropping back to the baseline after an additional $4 \mathrm{~h}$ (Fig. 5A, lane 5). Except for a second minor peak at $24 \mathrm{~h}$ after SA treatment (Fig. 5A, lane 6), this induction pattern is similar to that of propanoid glucosyltransferase (GT) mRNA, an immediate-early marker for SA induction (Horvath and Chua 1996).

We took advantage of the fact that CMV and CMV- $\Delta 2 \mathrm{~b}$ accumulated to similar levels in the systemic leaves when twoand three-leaf $N$. glutinosa seedlings were used for inoculation and compared the induction of Aox by SA in these virusinfected leaves. In uninfected leaves, SA treatment resulted in an approximately twofold increase in the accumulation of Aox transcript (Fig. 5B, compare lanes 1 and 2), a finding that is

Fig. 5. Induction of the alternative oxidase gene (Aox). A, Time-course induction profile of Aox by salicylic acid (SA). Nicotiana tabacum cv. Samsun nn seedlings were sprayed with $1 \mathrm{mM}$ SA, and total RNA was extracted at the time points indicated. Each lane was loaded with $10 \mu \mathrm{g}$ total RNA, and the blot was probed successively with cDNAs for AOX, immediate-early glucosyl transferase (GT), and 18S ribosomal RNA. B, Induction of Aox in Cucumber mosaic virus (CMV)-infected plants. At 3 weeks postinoculation with CMV, CMV- $\Delta 2 \mathrm{~b}$ (a mutant of CMV that does not express the CMV $2 b$ protein), or buffer, systemic Nicotiana glutinosa leaves were excised and cut into halves at mid vein. SA (1 $\mathrm{mM}$ ) was sprayed onto both sides of one half $(+)$ and water on the other half (-). Treated leaves were incubated in petri dishes under light for $3 \mathrm{~h}$ at $22^{\circ} \mathrm{C}$ before total RNA was extracted. RNA samples $(10 \mu \mathrm{g})$ were analyzed by Northern hybridization with probes specific for Aox, GT, (-)-strand CMV RNAs, and 18S rRNA. C, Aox mRNA levels during CMV infection. N. glutinosa seedlings were inoculated with $10 \mathrm{mM}$ phosphate buffer containing CMV- $\Delta 2 \mathrm{~b}$ or CMV virions $(5 \mu \mathrm{g}$ per $\mathrm{ml})$ or $10 \mathrm{mM}$ phosphate buffer alone, and leaf tissues were collected for RNA extraction at 1 (lanes 1-3) or 2 (lanes 4-6) days postinoculation. Each lane was loaded with $10 \mu \mathrm{g}$ of total RNA, and duplicate blots were probed with cDNAs for AOX and 18S rRNA or a RNA probe complementary to the $3^{\prime}$ end of CMV RNAs. Images for CMV RNAs were obtained after 60 (lanes 1-3) and 5 min (lanes 4-6) of exposure, respectively. D, Induction of Aox in Cmv2b transgenic lines. Eight-week-old seedlings of nontransgenic (Nt) $N$. tabacum or $\mathrm{Cmv} 2 \mathrm{~b}$ transgenic lines $\mathrm{C} 2 \mathrm{~b} 6$ and $\mathrm{C} 2 \mathrm{~b} 14$ were sprayed with water (lanes 1-3) or $1 \mathrm{mM} \mathrm{SA}$ (lanes 4-6). Total RNA was extracted from treated leaves $3.5 \mathrm{~h}$ after spraying. Each lane was loaded with $10 \mu \mathrm{g}$ of total RNAs, and the blot was probed successively with cDNAs for AOX, GT, Cmv2b, and 18S rRNA. similar to the earlier report in N. tabacum (Chivasa and Carr 1998). No obvious SA-mediated induction of Aox was observed in CMV-infected leaves (Fig. 5B, compare lane 5 with $6)$. In contrast, the accumulation of Aox transcript increased sevenfold after SA treatment in $C M V-\Delta 2$ b-infected leaves (Fig. 5B, compare lane 3 with 4). SA treatment induced stronger Aox expression in CMV- $\Delta 2 \mathrm{~b}$-infected leaves than it did in uninfected leaves, suggesting that $C M V-\Delta 2 b$ acted synergistically with SA in the induction of Aox. Indeed, the accumulation level of Aox at 1 dpi in N. glutinosa leaves inoculated directly with CMV- $\Delta 2 \mathrm{~b}$ was twice that of the level of
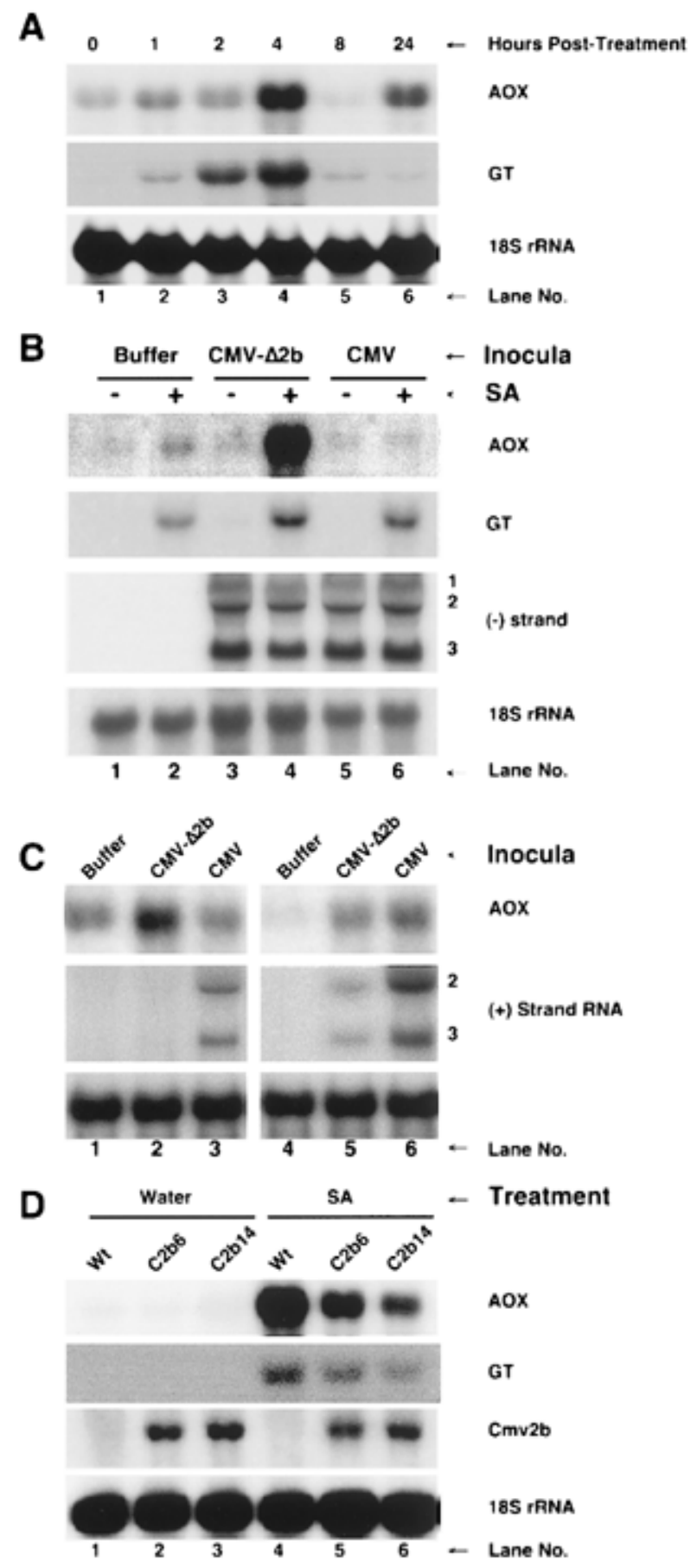

Vol. 14, No. 6, $2001 / 719$ 
those inoculated with CMV or buffer alone, even though CMV- $\Delta 2 \mathrm{~b}$ accumulated to much lower levels than CMV (Fig. $5 \mathrm{C}$, compare lane 2 with 3 ). At 2 (Fig. 5C, lanes 4 to 6 ) and 3 dpi (data not shown), however, Aox also was induced in CMVinoculated leaves, accumulating to a level similar to those inoculated with CMV- $\Delta 2 \mathrm{~b}$. Because the accumulation level of $\mathrm{CMV}$ was much higher than CMV- $\Delta 2 \mathrm{~b}$ at $2 \mathrm{dpi}$, the Aox expression could be considered suppressed in CMV-inoculated leaves. Thus, in the absence of Cmv2b expression, infection of $\mathrm{CMV}-\Delta 2 \mathrm{~b}$ led to a more rapid induction of Aox.

C2b6 and C2b14 are two independent Samsun nn lines that are transgenic for $C m v 2 b$. Both accumulated high levels of $C m v 2 b$ mRNA before and after SA treatment (Fig. 5D, compare lanes 2 with 5 and 3 with 6). Compared with nontransgenic plants, the transcriptional induction of Aox by SA was 2.5- and fourfold lower in C2b6 and C2b14, respectively (Fig. $5 \mathrm{D}$, compare lanes 4 with 5 and 6). The accumulation level of $G T$ was less affected by Cmv2b (approximately $50 \%$ lower in line $\mathrm{C} 2 \mathrm{~b} 14$ than in nontransgenic plants) (Fig. 5D, compare lane 4 with 6). These results indicate that expression of Cmv2b negatively affects the induction of Aox by SA in the absence of virus infection.

\section{Systemic infection of SA-deficient tobacco plants by $\mathrm{CMV}$ and $\mathrm{CMV}-\Delta \mathbf{2 b}$.}

The above experiments indicated a role for $\mathrm{Cmv} 2 \mathrm{~b}$ in antagonizing the virus resistance induced by the exogenous application of SA. We intended to determine whether such an antagonistic activity was relevant in natural CMV infections with the use of the nahG Samsun NN line (SH-L plants) (Bi et al. 1995). We found that gene expression for PRla and PR4a was induced significantly in wild-type Samsun NN plants infected systemically with CMV (Fig. 6, lane 4) or CMV- $\Delta 2$ b (Fig. 6, lane 3). In contrast, the expression levels of PRla and $P R 4 a$ were reduced significantly in SH-L plants infected with either CMV or CMV- $\Delta 2$ b (Fig. 6, lanes 5 and 6). This $n a h G-$ mediated reduction was more effective against PRla than $P R 4 a$. Thus, CMV infection of wild-type tobacco plants induced the transcription of SAR genes, an induction that was, in part, SA dependent.

Samsun NN plants infected with the subgroup II strain of CMV (Q) used in our studies show very mild systemic symptoms (Ding et al. 1996). We thus examined whether blockage of SA accumulation in the SH-L plants had any impact on the accumulation of CMV or CMV- $\triangle 2 \mathrm{~b}$ RNAs in inoculated and systemic leaves (Fig. 7). In inoculated leaves, at 2 dpi (Fig. 7, left panel), the accumulation of (+)- and (-)- strand CMV- $\Delta 2 \mathrm{~b}$ RNAs in the SH-L plants was approximately threefold of that in wild-type Samsun NN plants (Fig. 7, compare lane 1 with $3)$. This difference between wild-type and SH-L plants remained significant at $8 \mathrm{dpi}$ for the (-)-strand viral RNAs, although by this time point it was less obvious for the (+)-strand viral RNAs (Fig. 7, compare lane 5 with 7). In the systemic leaves, accumulation of (+)- and (-)-strand RNAs of CMV$\Delta 2 \mathrm{~b}$ was approximately fourfold higher in the SH-L plants (lane 11) than it was in the wild-type plants (lane 9). Thus, prevention of in vivo SA accumulation in the SH-L plants facilitated local and systemic infection by CMV- $\Delta 2 \mathrm{~b}$. This indicates that the compatible viral infection induced an appreciable level of virus resistance that was SA dependent. It was noticed that the accumulation of CMV- $\Delta 2 \mathrm{~b}$ in SH-L tobacco plants, either in the inoculated or systemic leaves, plants, either in the inoculated or systemic leaves, was lower than that of CMV in wild-type tobacco plants (Fig. 7, compare lane 6 with 7 and 10 with 11), except at 2 dpi (Fig. 7, compare lane 2 with 3). Therefore, blocking SA accumulation in SH-L plants allowed for an increased accumulation of CMV- $\Delta 2 \mathrm{~b}$ but did not fully restore the virus defect associated with $\mathrm{Cmv} 2 \mathrm{~b}$ deletion.

An intriguing accumulation pattern of CMV RNAs was observed in SH-L plants (Fig. 7). As for CMV- $\Delta 2 \mathrm{~b}$, the accumulation level of wild-type CMV RNAs at 2 and 8 dpi in the inoculated leaves of the SH-L plants was two to three times this level in equivalent leaves from nontransgenic plants. Surprisingly, a significantly decreased accumulation of CMV RNAs (approximately sevenfold) was observed in the systemic leaves of SH-L plants (Fig. 7, compare lane 10 with 12) compared with nontransgenic plants. In addition, no increase in viral RNA accumulation was associated with the expression of Cmv2b at 2 dpi in SH-L plants (Fig. 7, compare lane 3 with 4), although at $8 \mathrm{dpi}$, a substantial increase was observed (Fig. 7, compare lane 7 with 8). The accumulation level of CMV RNAs also was lower than in CMV- $\Delta 2 \mathrm{~b}$ in the systemic leaves in SH-L plants (Fig. 7, compare lane 11 with 12). Thus, as found for $\mathrm{CMV}-\Delta 2 \mathrm{~b}$, prevention of $\mathrm{SA}$ accumulation in tobacco is beneficial for local CMV infection but is detrimental to the systemic infection of CMV, in contrast to CMV- $\Delta 2 \mathrm{~b}$.

\section{DISCUSSION}

Recent pharmacological experiments carried out by Carr and colleagues demonstrated that SA-mediated resistance against viruses follows a distinct branch in tobacco, which is independent of $P R$ gene expression, sensitive to SHAM, and associated with Aox induction (Chivasa and Carr 1998; Chivasa et al. 1997; Murphy et al. 1999). Resistance to Turnip crinkle virus in A. thaliana also is SA-dependent, yet NPR1, ethylene, and JA independent (Kachroo et al. 2000), which further supports a novel SA-regulated resistance mechanism against viruses that is distinct from the known resistance pathways against bacterial and fungal pathogens.

Several lines of evidence presented in this manuscript support the role of $\mathrm{Cmv} 2 \mathrm{~b}$ as an antagonist of the SA-mediated virus resistance mechanism. First, CMV- $\Delta 2 \mathrm{~b}$ and CMV accumulate to similar levels in systemic leaves when young $N$. glutinosa seedlings are used for inoculation. Systemic infection of CMV- $\Delta 2 \mathrm{~b}$ but not CMV, however, was completely blocked by SA treatment, indicating a direct correlation between Cmv2b expression and the suppression of SA-mediated virus resistance. Secondly, as shown previously, CMV, in contrast to TMV and PVX, is insensitive to SA treatment in inoculated leaves (Chivasa et al. 1997; Naylor et al. 1998). We found that SA treatment caused a threefold reduction in the accumulation of CMV- $\Delta 2 \mathrm{~b}$ RNAs, suggesting a vital role for Cmv2b in the observed insensitivity of CMV to SA (Fig. 3). Third, Cmv2b is an active SA antagonist when incorporated into the genome of a SA-sensitive recombinant TMV (Fig. 4). Finally, expression of $\mathrm{Cmv} 2 \mathrm{~b}$ was linked tightly to inhibition of SA inducibility of Aox (Fig. 5). Our results indicate, for what we believe is the first time, that a virus-encoded protein is able to interfere with the SA-mediated resistance mechanism.

Previous reports have shown that plant defense-related genes are induced in compatible host-pathogen interactions 
(Mahajan et al. 1998; Zhou et al. 1997). It is not clear, however, whether these evidently moderate inductions play a role in plant defense. In this work, we demonstrate that systemic infection of $N$. tabacum by CMV triggered transcription of at least two SAR genes, PRla and PR4a. The induction was, in part, SA dependent because both mRNAs were reduced significantly in the SA-deficient SH-L plants (Fig. 6). We further showed that preventing in vivo SA accumulation by the $n a h G$ transgene significantly enhanced accumulation of CMV- $\Delta 2 b$ in the SH-L plants compared with wild-type plants, yet not up to the level of CMV in wild-type plants (Fig. 7). Thus, SA removal reduced, but did not eliminate, the host antiviral defense that is suppressed by $\mathrm{Cmv} 2 \mathrm{~b}$. These results indicate that tobacco plants, in response to the infection of a compatible pathogen such as CMV- $\Delta 2 \mathrm{~b}$, develop a $\mathrm{Cmv} 2 \mathrm{~b}$-sensitive virus resistance mechanism that does not require $\mathrm{SA}$ as an essential component but is potentiated significantly by SA.

One function of $\mathrm{Cmv} 2 \mathrm{~b}$ demonstrated previously is its ability to prevent the spread of transgene RNA silencing into newly emerging leaves in transgenic Nicotiana benthamiana plants (Brigneti et al. 1998; Lucy et al. 2000). Thus, our data could indicate that RNA silencing and SA-mediated virus resistance are independent antiviral pathways with unrelated Cmv2b targets. We cannot rule out that possibility, although we do favor an alternative explanation in which Cmv2b has a single target that is required for RNA silencing and SAmediated antiviral pathways. According to this idea, an increased in vivo SA accumulation, resulting from CMV infections or an exogenous application, potentiates a systemic RNA-silencing antiviral defense response in tobacco plants that is sensitive to Cmv2b. This potentiation could be achieved by up regulating expression of a required component

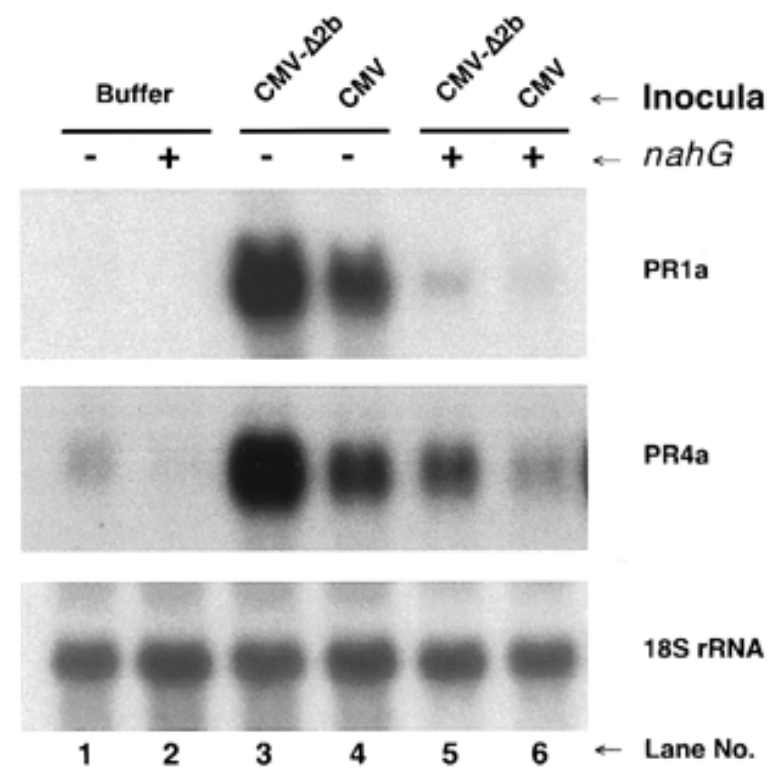

Fig. 6. Salicylic acid-dependent induction of PRla and $P R 4 a$ transcripts by Cucumber mosaic virus (CMV) and CMV- $\Delta 2 \mathrm{~b}$ (a mutant of CMV that does not express the CMV 2 b protein). Nicotiana tabacum cv. Samsun NN seedlings with (+) or without (-) the $n a h G$ transgene were inoculated with virions of CMV or CMV- $\Delta 2$ b. Total RNA $(10 \mu \mathrm{g})$ extracted from the third leaf above the inoculated leaves at 12 days postinoculation was used for Northern hybridization analysis with cDNAs for PR1a, PR4a, and 18S rRNA as probes. or down regulating expression of a negative regulator of systemic RNA silencing. Several genes essential for RNA silencing have been isolated from plants (Dalmay et al. 2000; Fagard et al. 2000; Mourrain et al. 2000); green alga (WuScharf et al. 2000); and fungi, worms, and flies (Ding 2000; Li and Ding 2001). In this regard, it is of interest to determine whether any of these genes or their plant homologs is responsive to SA.

This single-target hypothesis would help explain the differential response of young versus old $N$. glutinosa seedlings or young seedlings pretreated with SA to the infection of CMV. At very early stages of infection ( 1 to $4 \mathrm{dpi}$ ), Cmv2b expression always is correlated with a significantly enhanced viral RNA accumulation (Figs. 1 and 3, compare lane 1 with 3 and 2 with $4 ; 5$ C, compare lane 2 with 5 and 3 with 6). By 7 or 8 dpi in inoculated leaves, and thereafter in systemic leaves, this Cmv2b-associated positive effect was maintained only with the inoculated older leaves of mature plants (Fig. 1, compare lanes 6 and 10 with 8 and 12), immature leaves of young seedlings pretreated with SA (Fig. 3, compare lanes 6 and 10 with 8 and 12), or cucumber cotyledons (Ding et al. 1995a), but was greatly reduced when immature leaves of young seedlings were inoculated, particularly with regard to the (-)-strand viral RNAs (Figs. 1 and 3, compare lanes 5 and 9 with 7 and 11). It is known that RNA silencing of transgenes is under developmental control and transgenes constitutively targeted by RNA silencing are reset each generation after meiosis and often express to high levels in young seedlings before they are gradually silenced as plants mature (Elmayan and Vaucheret 1996). Thus, unlike mature plants, the RNA-silencing machinery is perhaps not fully operational in young seedlings without SA potentiation. As a result, young seedlings may be incapable of mounting an effective systemic RNA-silencing

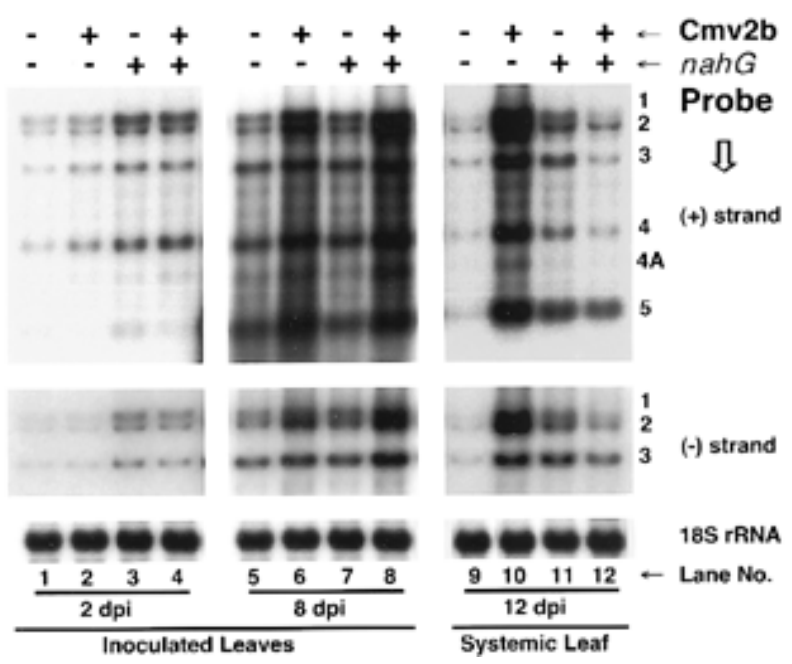

Fig. 7. Effect of salicylic acid removal on the accumulation of Cucumber mosaic virus (CMV) and CMV- $\Delta 2 \mathrm{~b}$ (a mutant of CMV that does not express the CMV 2b protein) RNAs in Nicotiana tabacum. N. tabacum cv. Samsun NN seedlings (5-6 leaf stage) with $(+)$ or without $(-)$ the $n a h G$ transgene were inoculated with CMV (+) or CMV- $\Delta 2$ b (-) with the use of linearized plasmid DNAs as inocula. Total RNAs were extracted from inoculated leaves at 2 and 8 days postinoculation (dpi), and the sixth leaf above the inoculated leaves at 12 dpi. Each lane was loaded with $2 \mu \mathrm{g}$ of total RNA, and the blot was hybridized successively with probes specific for the (-) and (+) strands of CMV RNAs and for $18 \mathrm{~S}$ rRNA. The CMV RNA species are indicated on the right. 
defense in response to virus infections, and systemic virus infection of these young seedlings would not require the silencing-suppressor activity encoded by $\mathrm{Cmv} 2 \mathrm{~b}$. Moreover, another reason why older leaves of mature $N$. glutinosa plants can mount an effective RNA-silencing offense could be a result of the higher level of SA contained in these leaves than in young leaves. Recent studies found that Arabidopsis leaves undergoing senescence contain higher levels of SA than do nonsenescent leaves (Morris et al. 2000).

Despite the drastic difference in disease symptoms, $N$. glutinosa plants inoculated at early stages of development with CMV- $\Delta 2 \mathrm{~b}$ and CMV show almost identical accumulation levels of genomic, subgenomic, and (-)-strand RNAs in systemic leaves (Figs. 1 [compare lanes 9 with 11] and 2). This indicates that CMV- $\Delta 2 \mathrm{~b}$ is not defective in long-distance transport in this host, and the failure of CMV- $\Delta 2 \mathrm{~b}$ to spread systemically in mature plants or young seedlings pretreated with SA is likely the result of a lack of suppression of active virus resistance by $\mathrm{Cmv} 2 \mathrm{~b}$. Moreover, the fact that $\mathrm{Cmv} 2 \mathrm{~b}$ is not associated with higher viral RNA accumulation levels in systemic leaves suggests that $\mathrm{Cmv} 2 \mathrm{~b}$ may enhance virulence by a mechanism that is independent of the suppression of virus RNA silencing. This is supported by the phenotypes of mutants generated in our recent analyses of Cmv2b (Lucy et al. 2000). Mutants of Cmv2b defective in silencing suppression (e.g., 2b6A) exhibited significantly reduced virulence in $N$. benthamiana, demonstrating the importance of silencing suppression in virulence. Nevertheless, these silencing suppression-defective mutants retained some ability to exert the virulence function. Furthermore, mutants deleted in either of the two highly conserved regions ( $2 \mathrm{~b} \Delta 5$ and $2 \mathrm{~b} \Delta 16)$ were wild-type suppressors of RNA silencing, although neither was an active virulence determinant in $N$. benthamiana (Lucy et al. 2000) or N. glutinosa (Ding et al. 1995a). This appears to be consistent with recent findings that mutations that block the RNA-silencing pathway have no obvious effect on plant development (Dalmay et al. 2000; Mourrain et al. 2000).

We showed that, although prevention of in vivo SA accumulation in the SH-L plants facilitated local infection by $\mathrm{CMV}$ at 2 and $8 \mathrm{dpi}$, it severely impaired systemic infection (Fig. 7). In contrast, local and systemic infection of CMV- $\Delta 2 b$ showed a significant improvement in the SH-L plants over the nontransgenic plants. In addition, Cmv2b expression was not associated with an enhanced viral RNA accumulation at the early stage of infection in SH-L tobacco (Fig. 7, compare lane 3 with 4), as found in nontransgenic tobacco, either with or without a prior SA treatment. This indicates a fundamental difference between wild-type and SA-deficient tobacco plants in their response to $\mathrm{Cmv} 2 \mathrm{~b}$ and suggests that $\mathrm{Cmv} 2 \mathrm{~b}$ may trigger an antiviral defense in the SH-L plant that only affects the systemic infection of CMV. The exact nature of the host response to $\mathrm{Cmv} 2 \mathrm{~b}$ in the absence of SA accumulation awaits further investigation.

Our previous data indicate that $\mathrm{Cmv} 2 \mathrm{~b}$ represents a novel gene acquired more recently than the other four genes encoded by CMV (Ding et al. 1994; Ding et al. 1995a). The newly discovered activity of Cmv2b in antagonizing SA-regulated virus resistance is expected to contribute to the invasiveness of CMV in certain host species (such as tobacco) that increase $\mathrm{SA}$ accumulation in response to the CMV challenge. This trait also may be critical for CMV to establish systemic infections in i) individual plants in the field in which SAR has been established as a result of prior challenges by incompatible pathogens; and ii) species such as tomato, potato, and soybean, which have basal SA levels far exceeding the elevated levels associated with SAR in tobacco (Raskin et al. 1990). Furthermore, CMV is transmitted in the field by aphids in a nonpersistent manner. Aphids begin to lose the ability to transmit CMV almost immediately after the acquisition feed ( $\mathrm{Ng}$ et al. 2000). Thus, the ability of Cmv2b to overcome the enhanced resistance in older leaves enables systemic infections to be established, even if virus-bearing aphids land on the lower parts of a mature plant.

Plants have evolved diverse defense mechanisms to protect themselves against viruses (Matthews 1991). Consequently, most plant species are resistant to the majority of plant viruses identified to date. Thus, it is of significant interest to understand the genetic and molecular basis for the exceptionally wide host range of $\mathrm{CMV}$, which includes more than 1,000 species in 365 genera from 85 families (Palukaitis et al. 1992). Our findings that $\mathrm{Cmv} 2 \mathrm{~b}$ is able to suppress the RNAsilencing and SA-mediated antiviral defenses of plants reveal novel counter-defensive strategies used by viral pathogens as well as provide further insights into the molecular basis of the wide host range of CMV. It is an important goal for our future work to determine whether the two activities encoded by Cmv2b operate by independent or related mechanisms.

\section{MATERIALS AND METHODS}

\section{Plant materials.}

$N$. glutinosa or N. tabacum seedlings were raised in 10.5$\mathrm{cm}$ pots under fluorescent light (approximately $45 \mu \mathrm{mol}$ per $\mathrm{s}$ per $\left.\mathrm{m}^{2}\right)$ in a growth room $\left(25^{\circ} \mathrm{C}\right)$. Virus inoculation was performed routinely with purified virions, which were diluted to $5 \mu \mathrm{g}$ (for CMV) or $1 \mu \mathrm{g}$ (for TMV) per $\mathrm{ml}$ in a buffer consisting of $10 \mathrm{mM}$ potassium phosphate and $5 \mathrm{mM} \beta$-mercaptoethanol ( $\mathrm{pH}$ 7.0). Inoculation with infectious plasmid DNAs was performed as described previously (Ding et al. 1995b). Unless otherwise stated, the second and third true leaves of each plant were inoculated. Inoculated plants were maintained in Conviron (Winnipeg, $\mathrm{MB}, \mathrm{Canada})$ growth chambers $\left(22^{\circ} \mathrm{C}\right.$ constant, $75 \%$ humidity, and a 16-h photoperiod) under a combination of fluorescent and incandescent lights (100 to $130 \mu \mathrm{mol}$ per s per $\mathrm{m}^{2}$ ). As indicated above, at each time point the two inoculated leaves and specified leaves above the inoculated leaves were excised from six to eight independent plants, which were snap frozen in liquid nitrogen and pooled for storage at $-80^{\circ} \mathrm{C}$. Each experiment was repeated at least twice.

\section{Plasmid constructs.}

pTMV-C2b has been described (Li et al. 1999). pTMV$\mathrm{C} \Delta 2 \mathrm{~b}$ was created similarly by cloning the corresponding pQCD2 $\Delta 2 \mathrm{~b}$ fragment (Ding et al. 1995b) into pTMV-30B (Shivprasad et al. 1999). The integrity of the inserted sequences was confirmed by sequencing the resultant clones and reverse transcription-polymerase chain reaction (RT-PCR) products from the recombinant TMV progenies in infected systemic leaves. Infectious TMV RNAs were prepared in vitro, as described (Li et al. 1999), and purified virions were isolated from Samsun nn seedlings inoculated with these RNA transcripts. 
The plant-transformation construct $\mathrm{pBI}-\mathrm{C} 2 \mathrm{~b}$ was made by inserting a HindIII-BglII fragment that contained the CMV $35 \mathrm{~S}$ promoter, full-length RNA 4A, and the $35 \mathrm{~S}$ terminator into the HindIII-BamHI site of pBI121 (Clontech, Palo Alto, CA, U.S.A.). An Agrobacterium tumefaciens.-mediated leaf disc transformation protocol (Horsch et al. 1988) followed, and 12 independent lines (in Samsun nn) were confirmed transgenic for pBI-C2b by Southern and Northern blot hybridization analyses. C2b6 and $\mathrm{C} 2 \mathrm{~b} 14$, which contain single and multiple copies of $C m v 2 b$, respectively, represent two of the highest expressing lines, as judged by Northern blot hybridization, and were selected for further analysis. Silencing suppression of a $\beta$-glucuronidase (GUS) transgene was observed when either line was crossed with the tobacco transgenic line 6 b5 (Elmayan and Vaulcheret 1996; H. S. Guo and S. W. Ding, unpublished data).

\section{SA treatment.}

SA treatment was performed according to Naylor et al. (1998), with modifications. N. glutinosa plants (two- to threeleaf stage) were sprayed once with $2 \mathrm{mM} \mathrm{SA}$ ( $\mathrm{pH} 6.5$, neutralized with $\mathrm{KOH}$ ) and watered with the SA solution applied to the top of the plants for an additional 4 days prior to inoculation. SA treatment continued after inoculation on alternate days, up to day 8. A similar plant treatment for TMV inoculation was performed with four- to five-leaf Samsun nn seedlings.

\section{Northern blot hybridization analysis.}

Extraction of total plant RNAs from pooled leaf samples and Northern blot hybridization analysis were carried out as described previously (Ding et al. 1995a; Li et al. 1999). Briefly, RNA samples were separated by electrophoresis through a $1.2 \%$ formaldehyde-agarose gel blotted onto Hybond-N membrane (Amersham Pharmacia Biotech, Buckinghamshire, U.K.) and hybridized to $\alpha-{ }^{32} \mathrm{P}-\mathrm{UTP}$-labeled, singlestranded RNA probes (Ding et al. 1995a) that were either complementary or corresponding to the $3^{\prime}$ terminal $340 \mathrm{nu}-$ cleotide of Q-CMV RNA 2 to detect for (+) and (-) strands of CMV RNAs, respectively. DNA probes to detect PRla mRNA and 18S rRNA have been described previously ( $\mathrm{Li}$ et al. 1999). DNA probes specific to mRNAs of Aox and $P R 4 a$ were obtained by RT-PCR with primers that amplify the region between nucleotide 150 and 888 of GenBank accession no. S71335 and between nucleotide 27 and 553 of accession no. X60281, respectively. The cDNA clone for immediate-early propanoid glucosyltransferase has been described previously (Horvath and Chua 1996). Detection of TMV RNAs was performed with a PCR-generated fragment corresponding to the $\mathrm{CP}$ gene in pTMV-30B. Each blot was either hybridized successively with different probes or multiple blots were produced from the same RNA samples. Measurement of band intensity was carried out with a GS-700 densitometer (BioRad, Hercules, CA, U.S.A.) or a GS-525 phosphor imager (Bio-Rad).

\section{ACKNOWLEDGMENTS}

We gratefully acknowledge J. Draper and L. Mur for SH-L tobacco seeds, N.-H. Chua for the immediate-early glucosyltransferase cDNA clone, and W. Dawson for TMV vector pTMV-30B. We are grateful to
W.-X. Li for technical assistance and Y. Fang for plant care. We also thank A. Lucy for purification of virions of CMV and CMV- $\Delta 2 b$, and to A. Lucy and S.-M. Wong for critical reading of the manuscript. This work was supported financially by the Singapore National Science and Technology Board.

\section{LITERATURE CITED}

Anandalakshmi, R., Pruss, G. J., Ge, X., Marathe, R., Mallory, A. C., Smith, T. H., and Vance, V. B. 1998. A viral suppressor of gene silencing in plants. Proc. Natl. Acad. Sci. USA 95:13079-13084.

Baulcombe, D. C. 1999. Gene silencing: RNA makes RNA makes no protein. Curr. Biol. 9:R599-601.

Bi, Y. M., Kenton, P., Mur, L., Darby, R., and Draper, J. 1995. Hydrogen peroxide does not function downstream of salicylic acid in the induction of PR protein expression. Plant J. 8:235-245.

Bowles, D. J. 1990. Defense-related proteins in higher plants. Annu. Rev. Biochem. 59:873-907.

Brigneti, G., Voinnet, O., Li, W. X., Ji, L. H., Ding, S. W., and Baulcombe, D. C. 1998. Viral pathogenicity determinants are suppressors of transgene silencing in Nicotiana benthamiana. EMBO J. 17:6739-6746.

Cao, H., Glazebrook, J., Clarke, J. D., Volko, S., and Dong, X. 1997. The Arabidopsis NPR1 gene that controls systemic acquired resistance encodes a novel protein containing ankyrin repeats. Cell 88:57-63.

Chivasa, S., and Carr, J. P. 1998. Cyanide restores N gene-mediated resistance to tobacco mosaic virus in transgenic tobacco expressing salicylic acid hydroxylase. Plant Cell 10:1489-1498.

Chivasa, S., Murphy, A. M., Naylor, M., and Carr, J. P. 1997. Salicylic acid interferes with tobacco mosaic virus replication via a novel salicylhydroxamic acid-sensitive mechanism. Plant Cell 9:547-557.

Covey, S. N., Al-Kaff, N. S., Langara, A., and Turner, D. S. 1997. Plants combat infection by gene silencing. Nature 385:781-782.

Dalmay, T., Hamilton, A., Rudd, S., Angell, S., and Baulcombe, D. C. 2000. An RNA-dependent RNA polymerase gene in Arabidopsis is required for posttranscriptional gene silencing mediated by a transgene but not by a virus. Cell 26:543-553.

Ding, S. W. 2000. RNA silencing. Curr. Opin. Biotechnol. 11:152-156.

Ding, S. W., Anderson, B. J., Haase, H. R., and Symons, R. H. 1994. New overlapping gene encoded by the cucumber mosaic virus genome. Virology 198:593-601.

Ding, S. W., Li, W. X., and Symon, R. H. 1995a. A novel naturally occurring hybrid gene encoded by a plant RNA virus facilitates long distance virus movement. EMBO J. 14:5762-5772.

Ding, S. W., Rathjen, J. P., Li, W. X., Swanson, R., Healy, H., and Symons, R. H. 1995b. Efficient infection from cDNA clones of cucumber mosaic cucumovirus RNAs in a new plasmid vector. J. Gen. Virol. 76:459-464.

Ding, S. W, Shi, B. J., Li, W. X., and Symons, R. 1996. An interspecies hybrid RNA virus is significantly more virulent than either parental virus. Proc. Natl. Acad. Sci. USA 93:7470-7474.

Dong, X. 1998. SA, JA, ethylene, and disease resistance in plants. Curr. Opin. Plant Biol. 1:316-323.

Durner, J., Shah, J., and Klessig, D. 1997. Salicylic acid and disease resistance in plants. Trends Plant Sci. 2:266-274.

Elmayan, T., and Vaulcheret, H. 1996. Expression of single copies of a strongly expressed $35 \mathrm{~S}$ transgene can be silenced posttranscriptionally. Plant J. 9:787-797.

Fagard, M., Boutet, S., Morel, J. B., Bellini, C., and Vaucheret, H. 2000. AGO1, QDE-2, and RDE-1 are related proteins required for posttranscriptional gene silencing in plants, quelling in fungi, and RNA interference in animals. Proc. Natl. Acad. Sci. USA 97:11650-11654.

Friedrich, L., Vernooij, B., Gaffney, T., Morse, A., and Ryals, J. 1995. Characterization of tobacco plants expressing a bacterial salicylate hydroxylase gene. Plant Mol. Biol. 29:959-968.

Friedrich, L., Lawton, K., Ruess, W., Masner, P., Specker, N., Rella, M. G., Meier, B., Dincher, S., Staub, T., Uknes, S., Métraux, J.-P., Kessmann, H., and Ryals, J. 1996. A benzothiadiazole derivative induces systemic acquired resistance in tobacco. Plant J. 10:61-70.

Gaffney, T., Friedrich, L., Vernooij, B., Negrotto, D., Nye, G., Uknes, S., Ward, E., Kessmann, H., and Ryals, J. 1993. Requirement of salicylic acid for the induction of systemic acquired resistance. Science 261:754-756. 
Gallitelli, D. 2000. The ecology of Cucumber mosaic virus and sustainable agriculture. Virus Res. 71:9-21.

Glazebrook, J. 1999. Genes controlling expression of defenses in Arabidopsis. Curr. Opin. Plant Biol. 2:280-286.

Hooft Van Huijsduijnen, R. A. M., Alblas, S. W., De Rijk, R. H., and Bol, J. F. 1986. Induction by salicylic acid of pathogenesis-related proteins and resistance to alfalfa mosaic virus in various plant species. J. Gen. Virol. 67:2135-2143.

Horsch, R. B., Fry, J., Hoffmann, N., Neidermeyer, J., Rogers, S. G., and Fraley, R. T. 1988. Leaf disc transformation. Pages A5:1-9 in: Plant Molecular Biology Manual. S. B. Gelvin and R. A. Schilperoort, eds. Kluwer Academic Publishers, Dordrecht, The Netherlands.

Horvath, D. M., and Chua, N. H. 1996. Identification of an immediateearly salicylic acid-inducible tobacco gene and characterization of induction by other compounds. Plant Mol. Biol. 31:1061-1072.

Kachroo, P., Yoshioka, K., Shah, J., Dooner, H. K., and Klessig, D. F. 2000. Resistance to turnip crinkle virus in Arabidopsis is regulated by two host genes and is salicylic acid dependent but NPR1, ethylene, and jasmonate independent. Plant Cell 12:677-690.

Kasschau, K. D., and Carrington, J. C. 1998. A counterdefensive strategy of plant viruses: Suppression of posttranscriptional gene silencing. Cell 95:461-470.

Lawton, K., Weymann, K., Friedrich, L., Vernooij, B., Uknes, S., and Ryals, J. 1995. Systemic acquired resistance in Arabidopsis requires salicylic acid but not ethylene. Mol. Plant-Microbe Interact. 8:863870.

Lawton, K. A., Friedrich, L., Hunt, M., Weymann, K., Delaney, T., Kessmann, H., Staub, T., and Ryals, J. 1996. Benzothiadiazole induces disease resistance in Arabidopsis by activation of the systemic acquired resistance signal transduction pathway. Plant J. 10:71-82.

Li, H. W., Lucy, A. P., Guo, H. S., Li, W. X., Ji, L. H., Wong, S. M., and Ding, S. W. 1999. Strong host resistance targeted against a viral suppressor of the plant gene silencing defense mechanism. EMBO J. 18:2683-2691.

Li, W. X., and Ding, S. W. 2001. Viral suppressors of RNA silencing. Curr. Opin. Biotechnol. 12:150-154.

Linthorst, H. J., Meuwissen, R. L., Kauffmann, S., and Bol, J. F. 1989. Constitutive expression of pathogenesis-related proteins PR-1, GRP, and PR-S in tobacco has no effect on virus infection. Plant Cell 1:285291.

Lucy, A. P., Guo, H. S., Li, W. X., and Ding, S. W. 2000. Suppression of post-transcriptional gene silencing by a plant viral protein localized in the nucleus. EMBO J. 19:1672-1680.

Mahajan, S. K., Chisholm, S. T., Whitham, S. A., and Carrington, J. C. 1998. Identification and characterization of a locus (RTM1) that restricts long-distance movement of tobacco etch virus in Arabidopsis thaliana. Plant J. 14:177-186.

Matthews, R. E. F. 1991. Plant Virology, 3rd ed. Academic Press, New York.

Morris, K., Mackerness, S. A. H., Page, T., John, C. F., Murphy, A. M., Carr, J. P., and Buchanan-Wollaston, V. 2000. Salicylic acid has a role in regulating gene expression during leaf senescence. Plant J. 23:677685 .

Mourrain, P., Beclin, C., Elmayan, T., Feuerbach, F., Godon, C., Morel, J. B., Jouette, D., Lacombe, A. M., Nikic, S., Picault, N., Remoue, K., Sanial, M., Vo, T. A., and Vaucheret, H. 2000. Arabidopsis SGS2 and $S G S 3$ genes are required for posttranscriptional gene silencing and natural virus resistance. Cell 26:533-542.

Mur, L. A. J., Naylor, G., Warner, S. A. J., Sugars, J. M., White, R. F., and Draper, J. 1996. Salicylic acid potentiates defense gene expression in tissue exhibiting acquired resistance to pathogen attack. Plant J. 9:559-571

Mur, L. A. J., Bi, Y. M., Darby, R. M., Firek, S., and Draper, J. 1997. Compromising early salicylic acid accumulation delays the hypersensitive response and increases viral dispersal during lesion establishment in TMV-infected tobacco. Plant J. 12:1113-1126.
Murphy, A. M., Chivasa, S., Singh, D. P., and Carr, J. P. 1999. Salicylic acid-induced resistance to viruses and other pathogens: A parting of ways? Trends Plant Sci. 4:155-160.

Naylor, M., Murphy, A. M., Berry, J. O., and Carr, J. P. 1998. Salicylic acid can induce resistance in plant virus movement. Mol. PlantMicrobe Interact. 11:860-868.

Ng, J. C., Liu, S., and Perry, K. L. 2000. Cucumber mosaic virus mutants with altered physical properties and defective in aphid vector transmission. Virology 276:395-403.

Pallas, J. A., Paiva, N. L., Lamb, C., and Dixon, R. A. 1996. Tobacco plants epigenetically suppressed in phenylalanine ammonia-lyase expression do not develop systemic acquired resistance in response to infection by tobacco mosaic virus. Plant J. 10:281-293.

Palukaitis, P., Roossinck, M. J., Dietzgen, R. G., and Francki, R. I. 1992. Cucumber mosaic virus. Adv. Virus Res. 41:281-348.

Rao, M. V., and Davis, K. R. 1999. Ozone-induced cell death occurs via two distinct mechanisms in Arabidopsis: The role of salicylic acid. Plant J. 17: 603-614.

Raskin, I. 1992. Role of salicylic acid in plants. Annu. Rev. Plant Physiol. Plant Mol. Biol. 43:439-463.

Raskin, I., Skubatz, H., Tang, W., and Meeuse, B. J. D. 1990. Salicylic acid levels in thermogenic and nonthermogenic plants. Ann. Bot. 66:369-373.

Ratcliff, F. G., Harrison, B. D., and Baulcombe, D. C. 1997. A similarity between viral defense and gene silencing in plants. Science 276:15581560.

Reymond, P., and Farmer, E. E. 1998. Jasmonate and salicylate as global signals for defense gene expression. Curr. Opin. Plant Biol. 1:404411.

Ryals, J., Weymann, K., Lawton, K., Friedrich, L., Ellis, D., Steiner, H. Y., Johnson, J., Delaney, T. P., Jesse, T., Vos, P., and Uknes, S. 1997. The Arabidopsis NIM1 protein shows homology to the mammalian transcription factor inhibitor I kappa B. Plant Cell 9:425-439.

Ryals, J. A., Neuenschwander, U. H., Willits, M. G., Molina, A., Steiner, H. Y., and Hunt, M. D. 1996. Systemic acquired resistance. Plant Cell 8:1809-1819.

Shirasu, K., Nakajima, H., Rajasekhar, V. K., Dixon, R. A., and Lamb, C. 1997. Salicylic acid potentiates an agonist-dependent gain control that amplifies pathogen signals in the activation of defense mechanisms. Plant Cell 9:261-270.

Shivprasad, S., Pogue, G. P., Lewandowski, D. J., Hidalgo, J., Donson, J., Grill, L. K., and Dawson, W. O. 1999. Heterologous sequences greatly affect foreign gene expression in tobacco mosaic virus-based vectors. Virology 255:312-323.

Staskawicz, B. J., Ausbel, F. M., Baker, B. J., Ellis, J. G., and Jones, J. D. G. 1995. Molecular genetics of plant disease resistance. Science 268:1809-1819.

Uknes, S., Winter, A. M., Delaney, T., Vernooij, B., Morse, A., Friedrich, L., Nye, G., Potter, S., Ward, E., and Ryals, J. 1993. Biological induction of systemic acquired-resistance in Arabidopsis. Mol. PlantMicrobe Interact. 6:692-698.

Ward, E. R., Uknes, S. J., Williams, S. C., Dincher, S. S., Wiederhold, D. L., Alexander, D. C., Ahl-Goy, P., Métraux, J. P., and Ryals, J. A. 1991. Coordinate gene activity in response to agents that induce systemic acquired resistance. Plant Cell 3:1085-1094.

White, R. F., Antoniw, J. F., Carr, J. P., and Woods, R. D. 1983. The effects of aspirin and polyacrylic acid on the multiplication and spread of TMV in different cultivars of tobacco with and without $\mathrm{N}$ gene. Phytopathol. Z. 107:224-232.

Wu-Scharf, D., Jeong, B. R., Zhang, C., and Cerutti, H. 2000. Transgene and transposon silencing in Chlamydomonas reinhardtii by a DEAHbox RNA helicase. Science 290:1159-1162.

Zhou, J., Tang, X., and Martin, G. B. 1997. The Pto kinase conferring resistance to tomato bacterial speck disease interacts with proteins that bind a cis-element of pathogenesis-related genes. EMBO J. 16:3207-3218. 